\title{
Recent Progressive Status of Materials for Solar Photovoltaic Cell: A Comprehensive Review
}

\author{
Jamilu Ya'u Muhammad ${ }^{1, ~ *, ~ A b u d h a r r ~ B e l l o ~ W a z i r i ', ~ A b u b a k a r ~ M u h a m m a d ~ S h i t u ', ~}$ \\ Umar Muhammad Ahmad ${ }^{1}$, Musa Hassan Muhammad ${ }^{3}$, Yusuf Alhaji ${ }^{3}$, Audu Taofeek Olaniyi ${ }^{1}$, \\ Auwal Abdulkadir Bala ${ }^{1}$ \\ ${ }^{1}$ Department of Mechanical Engineering, Bayero University, Kano, Nigeria \\ ${ }^{2}$ Department of Mechanical and Production Engineering, Abubakar Tafawa Balewa University, Bauchi, Nigeria \\ ${ }^{3}$ School of Technology, Binyaminu Usman Polytechnic, Hadejia, Nigeria
}

Email address:

jambcyfm@yahoo.com (J. Y. Muhammad)

${ }^{*}$ Corresponding author

\section{To cite this article:}

Jamilu Ya'u Muhammad, Abudharr Bello Waziri, Abubakar Muhammad Shitu, Umar Muhammad Ahmad, Musa Hassan Muhammad, Yusuf Alhaji, Audu Taofeek Olaniyi, Auwal Abdulkadir Bala. Recent Progressive Status of Materials for Solar Photovoltaic Cell: A Comprehensive Review. Science Journal of Energy Engineering. Vol. 7, No. 4, 2019, pp. 77-89. doi: 10.11648/j.sjee.20190704.14

Received: September 10, 2019; Accepted: October 8, 2019; Published: October 30, 2019

\begin{abstract}
Due to increase in demand of electricity and high environment hazard cause by fossil fuel in generation electricity, renewable energy (such as solar energy, wind energy and so on) researches are becoming mandatory to researchers especially scientists and engineers and in solar energy generation an electronic device is used to convert energy from sun into electricity which is known as solar photovoltaic cell and the efficiency of this device is improving by improving the materials used in manufacturing it. This paper was aimed to review the status of these materials for solar photovoltaic cell up to date, from the review it was discovered that the materials are classified based on the generations whereby their efficiencies are increasing from first generation to third generation. And the current market is mainly covered by the first two generations. The first generation comprises well-known medium/low cost technologies that lead to moderate yields. The second generation (thin-film technologies) includes devices that have lower efficiency albeit are cheaper to manufacture. The third generation presents the use of novel materials, as well as a great variability of designs, and comprises expensive but very efficient cells. Although there is fourth generation which their performance and stability was yet to be found as the review disclosed.
\end{abstract}

Keywords: Solar Photovoltaic Cell, Dye-Sensitized, Quantum Dot, Perovskite Solar Cell, Amorphous Silicon

\section{Introduction}

Generation of electricity from a source of energy that is sustainable and pollutants free has increases the interest of the researchers in a research environment. This source is known as Solar energy source which is a limitless source of energy and it is available freely $[1,2]$. The major benefit of solar energy over other conventional power generators is that the sunlight can be directly harvested into solar energy with the use of small and tiny photovoltaic (PV) solar cells [3, 4].

Photovoltaic solar cells conversion is the direct conversion of sunlight into electricity without any heat engine to interfere. The research focuses mainly in the field of photovoltaic for use of new materials with higher efficiency in converting solar energy into electricity [5-8]. The power conversion efficiency of photovoltaic (PV) solar cells has been improved from $1 \%$ to over $12 \%$, particularly through the efforts of the last decade [9-14].

Photovoltaic devices are rugged and simple in design requiring very little maintenance and their biggest advantage being their construction as stand-alone systems to give outputs from microwatts to megawatts. Hence they are used for power source, water pumping, remote buildings, solar home systems, communications, satellites and space vehicles, reverse osmosis plants, and for even megawatt scale power plants [15]. With such a vast array of applications, the demand for photovoltaic is increasing every year.

Despite of numerous applications of solar PV cells, the 
energy harnessed from solar PV cells has some limitations. Firstly, solar energy doesn't radiate at night. Secondly, the solar energy is almost not constant all the time. There must be plenty of sunlight available to generate electrical energy from a solar PV device [16-18]. Moreover, apart from daily fluctuations in the intensity of radiant energy, the solar energy is hindered to reach the earth during bad climatic conditions. For example, the amount of sunlight reaching the earth's surface depends on location, time as well as weather as it falls during winter season as compared to the summer, and the Sun's radiation is less intense $[17,18]$. To overcome these problems, solar energy must be stored elsewhere at night and the highly efficient solar cells and modules needs to be developed.

Photovoltaic (PV) cells technology is developing fast in recent years due to its unique advantages, such as, synthetic variability of materials [19], the possibility of producing lightweight, flexible, easily processed, and inexpensive solar cells and environmental sustainability [20-25] and among other photovoltaic cell technology in the past is hybrid photovoltaic power generation (HPVPG) technology [26-38].

\section{Materials for Solar Photovoltaic Cell}

Solar photovoltaic cell efficiency depends on the quality of the materials used in manufacturing solar cell. These materials were classified based on generations viz [39-41]:

a. First generation: These are based on a bulk material $p-n$ junction is represented by the silicon PV cells made of mono- or polycrystalline wafers.

b. Second generation: These are based on thin-film technology and possibly using various materials (Amorphus Silicon [a-Si], Cadmium Sulphate [CdS], Cadmium Telluride [CdTe], Copper Indium Gallium Diselenide [CIGS], etc.).

c. Third generation: These are high-efficiency photovoltaic cells which overcome the SQ limit by reducing losses due to non-absorbed photons and thermalized HCs. It is using advanced concepts employing several energy levels to harvest the solar spectrum more efficiently. The main concepts include tandem cells (TCs), light-frequency converters (up and down conversion), multiple-exciton generation (MEG) or carrier multiplication (CM), HC exploitation through selective contacts, intermediate band (IB) cells, etc.

\subsection{First (1 ${ }^{\text {st }}$ ) Generation Solar Cells (Wafer Based)}

The first-generation cells was first produced in 1954 and still representing the major part of the photovoltaic (PV) production. This can either be mono-crystalline or polycrystalline silicon wafers as detail given below:

\subsubsection{Mono-crystalline Silicon Solar Cell}

The mono-crystalline Silicon Solar Cell technology has achieved efficiencies of the order of $24.4 \%$ [44]. The monocrystalline Silicon solar cells include the growth of $\mathrm{Si}$ ingots from small mono-crystalline silicon seeds [46], and subsequently cut them to obtain mono-crystalline Silicon wafers, which manufactured by the Czochralski process [47]. This process allows the production of crystals with diameters ranging from 10 up to $300 \mathrm{~mm}$, and lengths from $50 \mathrm{~cm}$ up to $2 \mathrm{~m}[46,48]$.

Mono-crystalline material is widely used because of its high efficiency level as compared to multi-crystalline. Zhao et al. [42] reported the honeycomb textured mono-crystalline solar cells, with an efficiency of $24.4 \%$. However, it is essential to note that module efficiency is always lower than the cell efficiency.

One fundamental limitation of mono-crystalline silicon is its indirect bandgap, which leads to weak light absorption and requires wafers with thicknesses on the order of $100 \mathrm{~mm}$ in the absence of advanced light-trapping strategies. Key technological challenges for mono-crystalline silicon include stringent material purity requirements, high material use, restricted module form factor, and batch based cell fabrication and module integration processes with relatively low throughput [43].

\subsubsection{Poly-crystalline Silicon Solar Cell}

The poly-crystalline silicon solar cells are manufactured on poly-silicon wafers, which consist of small Silicon crystals randomly oriented. They possess many feature merits compared to the mono-crystalline Silicon solar cells among which are:

a. They involve less energy in their production and less associated greenhouse effects.

b. However, this type of PVCs can only reach efficiencies of $19.9 \%$ [10], smaller than mono-crystalline Silicon based cells. The main reason for this smaller efficiency is the lower material quality due to grain boundaries and defects, and the higher concentration of impurities. Therefore, the influence of recombination in polycrystalline silicon solar cells is higher than in monocrystalline Silicon solar cells, which leads to a slightly lower voltage. Current is also lower due to incomplete carrier collection in these devices [44].

Adamian et al. [48] worked on the possibility of using porous silicon layers as anti-reflection coating instead of antireflection coatings in common silicon solar cells $(\mathrm{ZnS})$ and made comparison of the photovoltaic and optical characteristics of investigated samples of solar cells with $\mathrm{ZnS}$ anti-reflection coating and with porous silicon anti-reflection coating. Bruton asserted that silicon technology has been the dominant one for the supply of power modules into photovoltaic applications and the likely changes are an increasing proportion of poly-crystalline silicon and monocrystalline silicon being used for high-efficiency solar cells while thinner wafers and ribbon silicon technology continue to grow [49]. Schlemm et al. [50] presented a magnetic field enhanced linear microwave plasma source and its application for deposition of silicon nitride anti-reflective and passivation layers on photovoltaic cells. Van der Zwaan and Rabl [51] presented current photovoltaic (PV) production cost ranges, both in terms of capacity installation and 
electricity generation of mono-crystalline silicon, polycrystalline silicon, amorphous silicon and other thin film technologies assessing possible cost reductions as expected according to the learning-curve methodology.

The result of the research conducted by McCann et al. [52] revealed that excellent bulk lifetimes and surface passivation can be maintained with a low pressure chemical vapor deposition (LPCVD) silicon nitride layer deposited on a silicon wafer, even following high-temperature treatments, provided a thin layer of silicon oxide is present under the nitride.

The solar cell efficiencies stand at $25.6 \%$ for monocrystalline silicon and $20.8 \%$ for poly-crystalline silicon solar cells; large-area module records are $22.4 \%$ for monocrystalline silicon and $18.5 \%$ for poly-crystalline silicon solar cells $[53,21]$.

\subsection{Second $\left(2^{\text {nd }}\right)$ Generation Solar Cells (Thin Film)}

The main aim of this generation is to reduce the high costs associated with the first generation by using lower amount of material and of poorer quality, deposited on cheap substrates based on thin-film technologies [54]. It includes amorphous silicon (a-Si), cadmium telluride/cadmium sulfide $(\mathrm{CdTe} / \mathrm{CdS})$ and copper indium gallium selenide (CIGS) solar cells.

\subsubsection{Amorphous Silicon (a-Si) Solar Cell}

Amorphous silicon (a-Si) solar cell is the most popular thin film technology with cell efficiencies of $5-7 \%$ and double- and triple-junction designs raising it to $8-10 \%$, but it is prone to degradation. Some of the varieties of amorphous silicon (a-Si) are amorphous silicon carbide (a-SiC), amorphous silicon germanium (a-SiGe), micro-crystalline silicon ( $\mu$-Si) and amorphous silicon-nitride (a-SiN) [15].

Hydrogen is required to dope the material, leading to hydrogenated amorphous silicon (a-Si: $\mathrm{H})$.

The use of a-Si: H can lead to operational problems since it can be degraded by sunlight: the thickness of the layer would decrease over time, and thicker layers would be required to ensure long-term operation. However, singlejunction and multi-junction devices with high efficiency and moderately good stability have been developed [55]. In addition, if the process involves a high concentration of $\mathrm{H}$, $\mu \mathrm{c}-\mathrm{Si}$ can be formed, which has fewer defects than a-Si and is more stable in the presence of solar radiation; the lab efficiencies of $\mu \mathrm{c}-\mathrm{Si}$ are in the range of $11.9 \%$ for singlejunction cells and $14.0 \%$ for multi-junction cells [21].

The typical production process of a-Si: $\mathrm{H}$ cells is a roll-toroll process [56]. Firstly, a cylindrical sheet, usually stainless steel, is unrolled to be used as a deposition surface. The sheet is washed, cut to the desired size, and printed with an insulating layer. Then, the a-Si: $\mathrm{H}$ is deposited on the reflector. Subsequently, the transparent conductive oxide (TCO) is deposited on the silicon layer. Laser cuts are then made to interconnect the different layers and, finally, the module is encapsulated.

The technology of a-Si: $\mathrm{H}$ for PV is based on two types of device design: a single-junction and multi-junction pi-n structure. Although major progress has been made in recent years in improving the deposition processes, material quality, device design, and manufacturing processes, the improvement of cell efficiency appeared to hit a bottleneck. It is generally recognized that any significant increase in efficiency can only be achieved by using multi-junction devices. It is indeed the case as shown by the achievement of a world-record stable efficiency of $13 \%$ (initial efficiency of $14.6 \%$ ) in a triple-junction structure [57]. The previous best stable efficiency was $11.8 \%$. This was accomplished by optimization of factors such as hydrogen dilution for film growth, bandgap profiling, current matching, and microcrystalline tunnel junction. Similarly, a new record in stabilized efficiency of $9.5 \%$ for $1200-\mathrm{cm}^{2}$ a-Si: H/a-SiGe: $\mathrm{H}$ has been reported recently [58].

Amorphous silicon is typically deposited by plasmaenhanced chemical vapor deposition (PECVD) at relatively low substrate temperatures of $150-300^{\circ} \mathrm{C}$. A $300 \mathrm{~nm}$ film of a-Si: H can absorb approximately $90 \%$ of above-bandgap photons in a single pass, enabling lightweight and flexible solar cells [59]. Amorphous silicon PV technologies held a global market share of $2 \%$ and a thin-film market share of $22 \%$ in 2013 [60]. An a-Si: H cell can be combined with cells based on nano-crystalline silicon (nc-Si) or amorphous silicon-germanium (a-SiGe) alloys to form a multi-junction cell without lattice-matching requirements. Most commercial a-Si: $\mathrm{H}$ modules today use multi-junction cells. Silicon is cheap, abundant, and non-toxic, but while a-Si: $\mathrm{H}$ cells are well suited for small-scale and low-power applications, their susceptibility to light-induced degradation (the Staebler-Wronski effect) [61] and their low efficiency compared to other mature thin-film technologies (13.4\% triple-junction cell record and $12.2 \%$ dual-junction module record) limit market adoption [53].

Due to random structure, a-Si has a high band gap of 1.7 $\mathrm{eV}$ [62] and hence, compared to mono-crystalline silicon, it has 40 times higher rate of light absorptivity [63]. It also holds the first position in current market amongst all thin film materials. The first amorphous thin film solar cell of $\sim 1 \mu \mathrm{m}$ thick was reported in 1976 with an efficiency of $2.4 \%$ by Carlson and Wronski [64]. In 1999, further improvements and potential of thin film solar cell is discovered by Rech and Wagner [65].

Yang et al. [57] discussed the advances made in amorphous-Si PV technology that led to the achievement of an AM 1.5, 13\% stable cell efficiency and set the foundation for the spectrum splitting triple-junction structure being manufactured by the roll-to-roll continuous deposition process [66]. Lund et al. [67] reported on laboratory and field studies being undertaken on the nature of the StaeblerWronski effect in amorphous silicon solar cells and how the stability of these cells is affected by different operating conditions and proposed a number of possible ways to reduce the Staebler-Wronski effect in a-Si: H solar cells. Tawada et al. [68] developed a series of production technologies for stable $8 \%$ efficiency direct-super-straight-type modules along 
with large area a-Si deposition technique.

\subsubsection{Cadmium Telluride (CdTe) and Cadmium Sulphide (CdS) Solar Cell}

Cadmium telluride (CdTe) is the leading thin-film PV technology, with a global PV market share of 5\% and a thinfilm market share of 56\% in 2013 [60]. CdTe is a favorable semiconductor for solar energy harvesting, with strong absorption across the solar spectrum and a direct bandgap of $1.45 \mathrm{eV}$ [59]. Record efficiencies of $21.0 \%$ for cells and $17.5 \%$ for modules are among the highest for thin-film solar cells, and commercial module efficiencies continue to improve steadily $[53,21]$.

The fundamental properties studied and presented in this research are the physical, electrical and optical characteristics of the deposited CdS layer. The discovery of the photovoltaic effect (PV) started with the discovery of Selenium in 1817 by Bezeluis who was the first to prepare elemental silicon. The PV effect was first observed in 1839 by French physicist, Edmon Becquerel [69-71]. This was followed by the discovery of photoconductivity in Selenium in 1873 by Willoughby Smith. This latter effect increased a flurry of activities which included the discovery of spectral sensitivity of Selenium photoconductors, the proposal of a light meter and the observation of the PV effect in a solid state Selenium structure by Adams and Day in $1876[69,71]$.

A major development in solar cell technology was evidenced in the1940's and 1950's when the "Czochralski method" was developed for producing highly pure crystalline silicon [72]. In 1954, work at Bell Telephone laboratory resulted in a $\mathrm{Si}$ cell with $4 \%$ efficiency, which was later increased this to $6 \%$ and then to $11 \%$ efficiency. Also in 1954 Cadmium Sulphide (CdS) p-n junction was produced with an efficiency of $6 \%$ [69]. CdS has a direct band gap of $2.42 \mathrm{eV}$ and usually has a wurzite hexagonal structure. $\mathrm{CdS}$ is a semiconductor with resistivity ranging from $10-3$ to $108 \Omega \mathrm{cm}$ [71].

Cadmium telluride solar cells are formed from cadmium and tellurium. Because of its ideal band gap of $1.45 \mathrm{eV}$, and longer stability [72], it is one of the promising materials in thin film technology. There are several remarkable results reported by Compaan [73], Schock and Pfisterer [74], Razykov et al. [75] and an efficiency of $10.6 \%$ and $11.2 \%$ was obtained on thin film 0.55- and 1-mm-thick CdTe by Nowshad et al. [76]. In addition, CdTe on plastic foil with an efficiency of $11.4 \%$ is reported by Upadhayaya et al. [77]. In general, $15 \%$ to $16 \%$ cell efficiency has been obtained by Britt and Ferekides [78], Aramoto et al. [79] and $\mathrm{Wu}$ et al. [80].

Reasonable progress has been made in recent years on $\mathrm{CdTe} / \mathrm{CdS}$ thin-film solar cells in which CdTe is the p-type absorber material enormously. The optimum bandgap (1.44 $\mathrm{eV}$ ) and high absorption coefficient due to direct optical transition make it an ideal PV material with theoretical efficiency of $30 \%$. One of the major advantages of $\mathrm{CdTe} / \mathrm{CdS}$ thin-film solar cells is its relatively easy and inexpensive manufacturing process. However, its conversion efficiency is low, similar to that of a-Si [63]. Some of the dominant problems of CdTe solar cell development include the difficulty of doping p-type $\mathrm{CdTe}$, the difficulty in obtaining low-resistance contacts to p-type $\mathrm{CdTe}$, there combination losses associated with the junction interface [81], and cadmium toxicity related precautions that have to be considered during the manufacturing process. The main problem in developing CdTe for PV application is the instability of cell and module performance. The fundamental mechanisms that govern carrier transport and the effects of the diffusion length $\mathrm{L}$, depletion width $\mathrm{W}$, and primary heterojunction vs. back junction on the CdTe thickness $t$ or back contact have not yet been well investigated and understood [82]. Recently, Tang et al. [83] fabricated cadmium sulfide core/copper sulfide shell nano-wire solar cells using a low-temperature solution-based cation exchange reaction. The open-circuit voltage and fill factor, which determine the maximum energy that a solar cell can produce, promote the inexpensive and convenient manufacturing method of nano-wire solar cells. These new nano-wire solar cells also demonstrate $5.4 \%$ energy conversion efficiency, which is comparable to those of planar solar cells. The ability to produce efficient nanowire-based solar cells with a solution-based process and using earth-abundant elements [84] can significantly reduce fabrication costs compared with existing high-temperature bulk material approaches. A number of relatively simple, low-cost methods have been used to fabricate solar cells with efficiencies in the range 10$16 \%$. Some of the low-cost deposition methods that show promise include:

a. Closed-space sublimation,

b. Spray deposition,

c. Electrodeposition,

d. Screen printing, and

e. Sputtering.

Most recently, a record $16 \%$ efficiency has been reported in a $\operatorname{CdS}(0.4-\mu \mathrm{m}) / \mathrm{CdTe}(3.5-\mu \mathrm{m})$ thin-film solar cell in which $\mathrm{CdS}$ and $\mathrm{CdTe}$ films are deposited by metal-organic CVD deposition (MOCVD) and CSS techniques, respectively [80]. Most of the high-efficiency solar cells use a superstrate device configuration in which CdTe is deposited on the $\mathrm{CdS}$ window layer. A typical device structure consists of glass $/ \mathrm{CdS} / \mathrm{CdTe} / \mathrm{Cu}-\mathrm{C} / \mathrm{Ag}$. In most cases, the postdeposition heat treatment of the CdTe layer in the presence of $\mathrm{CdCl}_{2}$ is essential for the optimization of device performance.

Ferekides et al. [85] presented work carried out on $\mathrm{CdTe} / \mathrm{CdS}$ solar cells fabricated using the close spaced sublimation (CSS) process that has attractive features for large area applications such as high deposition rates and efficient material utilization. Pfisterer [86] demonstrated the influence of surface treatments of the cells $\left(\mathrm{Cu}_{2} \mathrm{~S}-\mathrm{CdS}\right)$ and of additional semiconducting or metallic layers of monolayer-range thicknesses at the surface and discussed effects of lattice mismatch on epitaxy as well as wet and dry topotaxy and preconditions for successful application of topotaxy. Concerns about the toxicity of elemental cadmium and the scarcity of tellurium have motivated research on 
alternative material systems that exhibit similar ease of manufacturing but rely on abundant and non-toxic elements [87]. Richards et al. [88] demonstrated using ray-tracing simulations that the short-wavelength response of cadmium sulfide/cadmium telluride (CdS/CdTe) photovoltaic (PV) modules can be improved by the application of a luminescent downshifting (LDS) layer to the PV module that exhibit a poor internal quantum efficiency.

\subsubsection{Copper Indium Gallium Di-selenide (CIGS) Solar Cells}

The copper Indium Gallium di-selenide is another material in form thin-film of solar PV cell with general formula of $\mathrm{Cu}$ $\left(\mathrm{In}_{\mathrm{x}} \mathrm{Ga}_{1-\mathrm{x}}\right) \mathrm{Se}_{2}$ that varies its band gap value between 1.0-1.7 $\mathrm{eV}$ depending on the proportion of the elements in the compound [99]. Until 2006, the best efficiency of CIGS cells was $20 \%$ [90] and about $13 \%$ for modules [91]. In December 2013, Siva Power has reported highest cell efficiency of $18.8 \%$, which was confirmed by NREL [92].

Key technological challenges include high variability in film stoichiometry and properties, limited understanding of the role of grain boundaries, low open-circuit voltage due to structural and electronic inhomogeneity, and engineering of higher-bandgap alloys to enable multijunction devices [9395, 59]. Scarcity of indium could hinder large-scale deployment of CIGS technologies.

CIGS solar cells are designed in a standard substrate configuration, and it is also possible to deposit CIGS at relatively low temperatures on metal or polymer substrates to enable flexible solar products [96]. CIGS thin films are primarily deposited using co-evaporation/evaporation or sputtering, and to a lesser extent electrochemical deposition [97], or ion-beam-assisted deposition [98]. Since they are quaternary compounds, control of thin-film stoichiometry during manufacture is critical. There are also efforts to fabricate all or partly solution-deposited CIGS solar cells, with some predicting these could provide the ultimate path to ultra-low-cost $(<\$ 1 / W \mathrm{p})$, roll-to-roll, and flexible PV modules [99, 100]. CIGS module power conversion efficiencies typically range from 7 to $12 \%$, with small area modules yielding 14\%. The problem of CdS UV absorption is also of concern for CIGS, though suitable replacements to $\mathrm{CdS}$ have been shown in research and development and production CIGS technologies [101].

\subsection{Third $\left(3^{\text {rd }}\right)$ Generation Solar Cells}

Third generation solar photovoltaic technologies are solar PV cells that provide both a relatively high efficiency (approximately $\geq 20 \%$ ) and low cost (approximately $\leq \$ 200 / \mathrm{m}^{2}$ or $\leq \$ 1 / W \mathrm{p}$ ) as defined by M. Green [102].

Its aim is to develop devices with high efficiencies using the thin layer deposition techniques employed for the second generation and/or new configurations or materials [41]. In addition, third generations use non-toxic and very abundant materials, hence are suitable for the large-scale implementation of photovoltaic cells [41]. Further, they may employ new nanostructured or organic materials that could achieve high conversion efficiencies (greater than 60\%) using phenomena such as the hot carriers collection [39], the generation of multiple carriers (impact ionization), or new semiconductor architectures that contain multiple energy levels.

Considerable attention is paid to charge and energy transfer processes, and routes to optimize charge collection and improve the energy capture within the solar spectrum [103].

The most important technologies included in the third generation solar PV cells are:

a) Multi-junction (MJ) solar cells;

b) Quantum dot (QD) solar cells;

c) Dye-sensitized solar cells (DSSCs);

d) Perovskite solar cells; and

e) Organic and polymer solar cells;

\subsubsection{Muti-junction Solar Cells}

Multi-junction (MJ) solar cells comprise multiple $p-n$ junctions made of different semiconductor materials, and each of them produces electric current in response to different wavelengths of light, thus increasing the conversion of incident sunlight into electrical energy and the device efficiency [43]. The idea of using different materials with different band gap is proposed to take advantage of the maximum possible photons and it's also called tandem solar cell. The whole cell can be made of the same material or different ones, offering a wide range of design possibilities [104].

The cells are typically monolithically integrated and series connected using a tunnel junction, with current matching between the cells provided by adjusting the bandgap and thickness of each cell [105]. The theoretical entitlement of multiple bandgaps has been analyzed and shown to be $44 \%$ for two bandgaps, $49 \%$ for three bandgaps, $54 \%$ for four bandgaps, and $66 \%$ for an infinite number of bandgaps [106].

The tandem arrangement can be achieved with the different thin film materials, according to their band gaps [107]. Yamaguchi et al. [108] reviewed efficiency and status of multi-junction solar cells. The theoretical efficiency of a single-junction cell is around $31 \%$ [109]. Guha [110] discovered that the stabilized efficiency of single junction cell was $9.3 \%$, for double junction $12.4 \%$, whereas $13 \%$ was for triple junction. The strategy of double junction of Hydrogenated amorphous silicon (a-Si: H) intrinsic layers was developed by Fuji Electric and Co. (Japan) and Phototronics (Germany) (part of RWE Schott) with a stabilized laboratory efficiency of approximately $8.5 \%$ for cells and $5.5 \%$ for commercially available module efficiency [111]. On the basis of concept intermediate Transparent Conducting Oxides (TCO) reflector layer for light trapping, Yamamoto et al. [112] showed the efficiency of $14.7 \%$. Nevertheless, in June 2013, Sharp hit a world record of $44.4 \%$ triple junction solar cell, which was verified by Fraunhofer Institute [113].

\subsubsection{Quantum Dot (QD) Solar Cells}

The quantum dot is a nano-crystalline structure between 2$10 \mathrm{~nm}$ in size $[115,116]$, like porous $\mathrm{Si}$ or porous $\mathrm{TiO}_{2}$ [114]. 
Solar cells made from these materials are called Quantum Dot (QD) Solar cells which are also known as Nano-crystal Solar cells.

It is made by the method of epitaxial growing on a substrate crystal. The quantum dots are surrounded by high potential barriers in a three dimensional shape, and the electrons and electron holes in the quantum dot become a discrete energy as it is confined in a small space. Consequentially, the energy state of the ground-state energy of the electrons and electron holes in the quantum dot would be subject to the size of the quantum dot $[117,118]$.

Current research on quantum dot solar cell discovered the cell efficiency from approximately $1-11.6 \%$ [119-122] when combined with other third generation technologies such as DSSCs [123], and its theoretical efficiency was estimated to be $63 \%$ [124]. Antolin et al. [125] investigated the photocurrent produced by double-absorption of sub band gap photons predicted by the IBSC model that has been measured in QD-IBSCs (Quantum dot-Intermediate band solar cells) fabricated with InAs/GaAs material using a modulated technique with two light beams.

\subsubsection{Dye Sensitized Solar Cells (DSSC)}

Dye-sensitized solar cells (DSSC) are among the best nanotechnology-based for harvesting material for solar photovoltaic technologies [126-128]. The first dye-sensitized (DSSC) solar cell was introduced by Gratzel M. in Swiss federal institute of technology [129, 17].

This is a hybrid organic-inorganic design, in which a porous, nano-crystalline titanium dioxide $\left(\mathrm{TiO}_{2}\right)$ film is used as the electron conductor, which is in contact with an electrolyte solution that also contains organic light-absorbing dyes near the interfaces. Charge transfer occurs at the interface, such that holes are transported in the electrolyte. Power conversion efficiencies of approximately $11 \%$ have been demonstrated and commercialization of dye-sensitized photovoltaic modules is under way [130]. The novelty in the dye-sensitized (DSSC) solar cells arise due to the photosensitization of nano grained $\mathrm{TiO}_{2}$ coatings coupled with the visible optically active dyes, thus increasing the efficiencies greater than 10\% [131-134].

Millington et al. [135] studied the performance of 49 commercial mordant dyes as sensitizers in DSSCs and compared them to that of N3 ruthenium complex. Although $\mathrm{N} 3$ led to the highest output, six mordant dyes produced photocurrents higher than $0.2 \mathrm{~mA}$, and the UV-visible spectra of the dye-complexed photoanodes suggested that some mordant dyes are more strongly bound to the $\mathrm{TiO}_{2}$ surface than N3.

Kim et al. [136] reported a synthetic strategy of organic dyes to achieve high photovoltage for DSSCs. They employed organic dyes with non-planar spacer groups, and proved that non-planar geometry in organic dyes is one of the important factors that affect photovoltage. Using natural dyes as sensitizers are promising since they are potential alternatives to expensive and rare organic dyes. They also offer environmental friendliness, low-cost production, designable polychrome modules, simple preparation technique, and wide availability. Hara and Arakawa [137] worked on different components and operating principles of dye-sensitized solar cells (DSSC). The four-energy levels of the DSSC are:

a. The excited state, the ground state, and the fermi level of $\mathrm{TiO}_{2}$ electrode and;

b. The redox potential of the iodide/triiodide present at the electrolyte.

\subsubsection{Polymer and Organic Solar Cells}

Organic solar photovoltaic cells are solar cells that use conductive organic polymers or small organic molecules for light absorption and charge transport to produce electricity from sunlight [139-145]. Polymer solar cells are generally flexible solar cells due to the polymer substrate. The first polymer solar cells were invented by the research group of Tang et al. [146] at Kodak Research Laboratory. The maximum possible power conversion efficiency is difficult to obtain from first principles due to the difficulty in modeling complex junction geometries and the corresponding exciton dissociation dynamics; however, an upper bound of $20 \%$ has been estimated [147]. Polymer and organic solar cells have estimated efficiency of $11.1 \%$, with module efficiencies reaching $8.7 \%[21,53]$.

Dou et al. [148] designed a special low band gap polymer poly $\{2,6$-4, 8-di (5-ethylhexylthienyl) benzo [1, 2-b; 3, 4-b] dithiophene-alt-5-dibutyloctyl-3, 6-bis (5-bromothiophen-2yl) pyrrolo [3, 4-c] pyrrole-1, 4-dione (PBDTT-DPP) with band gap of $\sim 1.45 \mathrm{eV}$. This material is specially designed with narrow absorption to avoid the overlap with wide band gap polymer P3HT. Regular and inverted structure single junction devices both showed6-7\% efficiency with fill factor close to $70 \%$. This forms an excellent combination with a P3HT: ICBA cell as the wideband gap cell resulting in a tandem efficiency of $8.62 \%$. Jorgensen et al. [149] presented an understanding of stability/degradation in organic and polymer solar cell devices and discussed the methods for studying and elucidating degradation and enhancing the stability through the choice of better active materials, encapsulation, application of getter materials and UV filters.

Dennler et al. [150] showed that to achieve15\% efficiency in a tandem solar cell, the WBG cell donor should have a band gap of $1.6 \mathrm{eV}$, and the LBG cell donor should have a band gap of $1.3 \mathrm{eV}$, under the assumption that both cells have a flat quantum efficiency of $65 \%$. Yue et al. [151] developed an organic PV device based on triplet complex Re-Phen with power conversion efficiency of $4 \%$ which is high compared to the devices based other metal complexes, state increasing the PV efficiency owing to the existence of a charge transfer absorption. Mozer et al. [152] presented successful strategies towards improved photovoltaic performance using various novel materials, including double-cable polymers, regioregular polymers and low bandgap polymers demonstrating that the bulk heterojunction concept is a viable approach towards developing photovoltaic systems by inexpensive solution-based fabrication technologies. 
Shrotriya et al. first demonstrated a semi-transparent version of MEH-PPV based polymer solar cell, and stacked it directly with another non-transparent solar cell to realize the concept [153].

Wei et al. [154] demonstrated efficient white organic lightemitting device based on exciplex with higher luminance and luminous efficiency and this bi-functional device with electroluminescence (EL) and PV performances is promising to be used as white displays or backlight source in the future as it can be charged by solar energy through additional apparatus free of work and can also be used as an optical sensor to UV light. Bernede et al. [155] studied different cell configurations: two-layer D/A organic solar cells deposited by vacuum evaporation and bulk $\mathrm{D} / \mathrm{A}$ heterojunction material based on a discontinuous D/A network thin film obtained by spin coating. Yakimov et al. showed that an ultra-thin evaporated metal between two sub-cells can lead to the addition of their photovoltages [156].

\subsubsection{Perovskite Solar Cells}

Perovskite is a crystal structure with a general crystal structure $A B X_{3}$, where $\mathrm{A}$ is a cation with +1 vacancy of electron, $\mathrm{B}$ is also cation but with +2 vacancies and $\mathrm{X}$ is an anion which can either be halogen or oxygen. The most commonly studied perovskite solar cell is methylammonium lead trihalide $\left(\mathrm{CH}_{3} \mathrm{NH}_{3} \mathrm{PbX}_{3}\right.$, where $\mathrm{X}$ is a halogen ion such as $\mathrm{I}^{-}, \mathrm{Br}^{-}, \mathrm{Cl}-$ ), with an optical bandgap between $2.3 \mathrm{eV}$ and $1.6 \mathrm{eV}$ depending on halide content. Formamidinum lead trihalide $\left(\mathrm{H}_{2} \mathrm{NCHNH}_{2} \mathrm{PbX}_{3}\right)$ has also shown promise, with bandgaps between $2.2 \mathrm{eV}$ and $1.5 \mathrm{eV}$. The minimum bandgap is closer to the optimal for a single-junction cell than methylammonium lead trihalide, so it should be capable of higher efficiencies [157]. A common concern is the inclusion of lead as component of the perovskite materials; solar cells based on tin-based perovskite absorbers such as $\mathrm{CH}_{3} \mathrm{NH}_{3} \mathrm{SnI}_{3}$ have also been reported with lower power conversion efficiencies [158].

Perovskite cells have improved their efficiency from an initial value of $3.8 \%$ in 2009 [159] to $22.13 \%$ in 2018 in single-junction architectures [160, 161]. Also, various research groups have already reported to have power conversion efficiencies more than $20 \%$ [162]. The maximum efficiency that can be obtained from two-junction series connected solar cell is $47 \%$. At this peak efficiency, the top cell has a bandgap of $1.63 \mathrm{eV}$ and the bottom cell has a bandgap of $0.96 \mathrm{eV}$ [163].

Park et al. first reported long- term stable perovskite solar cells with PCE as high as 9.7\% [164]. A long-term stable perovskite solar cell was designed in 2012 by replacing liquid with solid HTM. Since then, solid-state perovskitecontaining solar cells have been called perovskite solar cells. Park et al. reported PCE of $6.5 \%$ using $\mathrm{CH}_{3} \mathrm{NH}_{3} \mathrm{PbI}_{3}$. At the given $\mathrm{TiO}_{2}$ film thickness of about $3.6 \mathrm{~mm}, \mathrm{CH}_{3} \mathrm{MH}_{3} \mathrm{PbI}_{3}$ perovskite showed an absorption coefficient that was 10 times greater than that of the conventional ruthenium-based molecular dye [165]. Since organo-lead halide perovskite is an ionic crystal, it easily dissolves in a polar solvent. Thus, organo-lead halide perovskite is not suitable for liquid electrolyte-based sensitized solar cells because of stability concerns. This instability problem was solved by substituting a solid hole conductor for the liquid electrolyte. Miyasaka et al. applied $3 \mathrm{D}$ perovskite $\mathrm{CH}_{3} \mathrm{NH}_{3} \mathrm{PbX}_{3}(\mathrm{X}=\mathrm{Br}$, I) as an inorganic sensitizer in dye-sensitized solar cells in 2009. They demonstrated a power conversion efficiency (PCE) of $3.1 \%$ for $\mathrm{X}=\mathrm{Br}$ and $3.8 \%$ for $\mathrm{X}=\mathrm{I}$ [163]. As of June 10th 2014 , the certified record PCE of $17.9 \%$ was achieved by the Korean Research Institute of Chemical Technology (KRICT), which was certified by the National Renewable Energy Laboratory (NREL) [166].

\section{Potential Applications, Challenges and Future Trends of Solar Cells Technologies}

\subsection{Potential Applications of Solar Cells Technologies}

Solar cells having versatile potential applications, some of which are as follows:

a. Power generation: Solar photovoltaic cells are used in solar energy plant to generate steam which would then use to rotate turbines through photoelectric technologies and thermoelectric technologies, electricity would be generated.

b. Lighting: Solar photovoltaic cells are used in lighting houses as off-grid (the light of sun in day time are stored in a batteries and it then converted into electricity) or tie-grid to generate electricity to the houses, offices, schools, companies etc.

c. Solar Cars: It is an electrical vehicle which is recharged form solar energy. Solar PV cells are used on this car that absorb light and then convert it into electrical energy. This electrical energy is stored in batteries used with the car, so that in night time the vehicles will used it to operate.

d. Swimming pools: Swimming pools are great joy for kids and adults in all seasons. But during winters it is tough to keep water hot in these pools with minimum power usage. Solar energy can help many in this matter as well. You can add a solar blanket in the pool that will keep the water hot with energy generated from sunlight. Besides this you can install a solar hot water heating system with solar hot water heating panels.

e. Ventilation system: At many places solar energy is used for ventilation purposes. It helps in running bath fans, floor fans, and ceiling fans in buildings. Fans run almost every time in a building to control moisture, and smell and in homes to take heat out of the kitchen. It can add heavy amount on the utility bills, to cut down these bills solar energy is used for ventilation purposes.

f. Building-Integrated Photovoltaic (BIPV): The use of photovoltaic (PV) modules in structural features whose primary purpose is not electricity generation (e.g., windows, skylights, shingles, tiles, curtains, and canopies). 


\subsection{Challenges and Future Trends of Solar Cell Technologies}

With improvement in efficiency of one generation to another, there are some challenges in most of the solar cells as mentioned viz:

a) The challenges for wafer-based solar cells include stringent material purity requirements, high material use, restricted module form factor, and batch based cell fabrication and module integration processes with relatively low throughput.

b) The technological challenges for thin-film Silicon solar cells include enhancing light absorption by employing advanced anti-reflection and light-trapping strategies, reducing recombination losses by engineering higherquality crystalline films, reducing processing temperatures to enable flexible substrates and modules without sacrificing material quality, and developing new methods for high-throughput inline module integration.

c) The key challenges for emerging multi-junction solar cell technology include improving long-term reliability and large-area uniformity, reducing materials use, and optimizing cell architectures for variable operating conditions.

d) Key challenges include incomplete understanding of quantum dot (QD) surface chemistry [167-170] and low open-circuit voltages that may be limited fundamentally by mid-gap states or inherent disorder in quantum dot (QD) films [171, 172].

e) Limited long-term stability under illumination and high temperatures, low absorption in the near-infrared, and low open-circuit voltages caused by interfacial recombination is the key dye-sensitized solar cells [59]. Moreover, there are certain challenges like degradation of dye molecules and hence stability issues [129]. This is due to poor optical absorption of sensitizers which results in poor conversion efficiency.

f) Key challenges include refined control of film morphology and material properties, high sensitivity to moisture, unproven cell stability, and the use of toxic lead [173].

g) Organic and polymer solar cell's challenges consist of poor long-term stability [174], inefficient exciton transport [141, 145, 175], low large-area deposition yield, and low ultimate efficiency limits [176].

\section{Conclusions and Recommendations}

Due to increase in the global energy consumption and several different technologies are used to meet the energy demand. Solar energy technology has been developed as one of the most demanding renewable sources of electricity. In this article, the materials for solar cell are extensively reviewed and finally it was discovered that the current commercial products used to generate solar power, such as silicon or thin-film based technologies, are expensive because they are processed using vacuum-based techniques. And also the Commercial thin-film technologies could avoid critical material constraints and remain viable at a deployment scale of up to hundreds of gigawatts by 2050. Moreover, it was found that the production process for perovskite panels is very straightforward, but researchers still have to test the material under different conditions to better understand its properties, before companies embark on industrial-scale production.

It was recommended that to achieve the objectives of photovoltaics, the efficiency of solar cells should be improved without any compromise on the processing cost of these devices.

\section{References}

[1] Chu, Y. and Meisen, P. (2011) Review and Comparison of Different Solar Energy Technologies. Report of Global Energy Network Institute (GENI), Diego.

[2] Choubey, P. C., Oudhia, A. and Dewangan, R. (2012) A Review: Solar Cell Current Scenario and Future Trends. Recent Research in Science and Technology, 4, 99-101.

[3] McEvoy, A., Castaner, L. and Markvart, T. (2012) Solar Cells: Materials, Manufacture and Operation. 2nd Edition, Elsevier Ltd., Oxford, 3-25.

[4] Fahrenbruch, A. L. and Bube, R. H. (1983) Fundamentals of Solar Cells. Academic Press Inc., New York.

[5] Shogo I.; Takashi Y.; Kazuyuki M.; Akimasa Y.; Shigeru N.: Monolithically integrated CIGS submodules fabricated on flexible substrates. http://ieeexplore.ieee.org/stamp/stamp.jsp?tp=\&arnumber=56 14095

[6] Muñoz D.; et al.: Towards high efficiency on full wafer a-Si: $\mathrm{H} / \mathrm{c}-\mathrm{Si}$ heterojunction solar cells: $19.6 \%$ ON $148 \mathrm{~cm}$. $\mathrm{http}$ ://ieeexplore.ieee.org/stamp/stamp.jsp?tp=\&arnumber $=56$ 14179

[7] Tuma J.; Rusek S.; Martínek Z.; Chemišinec I.; Goňo R.: Spolehlivost v elektroenergetice. Conte, Praha, 2006, ISBN 80-239-6483-6.

[8] Green M. A.; et al.: Hot carrier solar cells: Challenges and recent progress. $\mathrm{http}$ ://ieeexplore.ieee.org/stamp/stamp.jsp?tp=\&arnumber $=56$ $14200 \backslash$

[9] Dou, L. T., You, J. B., Hong, Z. R., Xu, Z., Li, G., Street, R. A., et al. (2013). 25 $5^{\text {th }}$ anniversary article: a decade of organic/polymeric photovoltaic research. Adv. Mater. 25, 6642-6671. doi: 10.1002/adma.201302563.

[10] Green, M. A., Hishikawa, Y., Warta, W., Dunlop, E. D., Levi, D. H., Hohl-Ebinger, J., et al. (2017). Solar cell efficiency tables (version 50). Prog. Photovol. 25, 668-676. doi: 10.1002/pip.2909.

[11] Jung, J. W., Jo, J. W., Jung, E. H., and Jo, W. H. (2016). Recent progress in high efficiency polymer solar cells by rational design and energy level tuning of low bandgap copolymers with various electron-withdrawing units. Org. Electron. 31, 149-170. doi: 10.1016/j.orgel.2016.01.034. 
[12] Li, S., Ye, L., Zhao, W. C., Zhang, S. Q., Mukherjee, S., Ade, H., et al. (2016). Energy-level modulation of small-molecule electron acceptors to achieve over $12 \%$ efficiency in polymer solar cells. Adv. Mater. 28, 9423-9429. doi: 10.1002/adma.201602776.

[13] Singh, R. P., and Kushwaha, O. S. (2017). Progress towards efficiency of polymer solar cells. Adv. Mater. Lett. 08, 02-07. doi: 10.5185/amlett.2017.7005.

[14] Zhao, W., Li, S., Yao, H., Zhang, S., Zhang, Y., Yang, B., et al. (2017). Molecular optimization enables over 13\% efficiency in organic solar cells. J. Am. Chem. Soc. 139, 7148-7151. doi: $10.1021 /$ jacs. 7 b02677.

[15] Parida B.; Iniyan S.; Goic R. (2011). A review of Solar Photovoltaic Technologies. Renewable and Sustainable Energy and Reviews, (15). 1625-1636. Doi: 10.1016/j.rser.2010.11.032.

[16] Rana, S. (2013) A Study on Automatic Dual Axis Solar Tracker System using 555 Timer. International Journal of Scientific \& Technology Research, 1, 77-85.

[17] Bagher, A. M., Vahid, M. M. A. and Mohsen, M. (2015) Types of Solar Cells and Application. American Journal of Optics and Photonics, 3, 94-113.

[18] Whitburn, G. (2012) Exploring Green Technology, Fundamental Advantages and Disadvantages of Solar Energy.

[19] Liu, Z. L., Sun, J. M., Zhu, Y. X., Liu, P., Zhang, L. J., Chen, J. W., et al. (2015). Low band-gap benzodithiophenethienothiophenecopolymers: the effect of dual twodimensional substitutions on optoelectronic properties. Sci. China Chem. 58, 267-275. doi: 10.1007/s11426-014-5223-7

[20] Chen, K. S., Yip, H. L., Salinas, J. F., Xu, Y. X., Chueh, C. C., and Jen, A. K. Y. (2014). Strong photocurrent enhancements in highly efficient flexible organic solar cells by adopting a microcavity configuration. Adv. Mater. 26, 3349-3354. doi: 10.1002/adma.201306323

[21] Green, M. A., Emery, K., Hishikawa, Y., Warta, W., and Dunlop, E. D. (2015). Solar cell efficiency tables (Version 45). Prog. Photovol. 23, 1-9. doi: 10.1002/pip.2573.

[22] Kaltenbrunner, M., White, M. S., Glowacki, E. D., Sekitani, T., Someya, T., Sariciftci, N. S., et al. (2012). Ultrathin and lightweight organic solar cells with high flexibility. Nat. Commun. 3: 770. doi: 10.1038/ncomms1772.

[23] Singh, R. P., and Kushwaha, O. S. (2013). Polymer solar cells: an overview. Macromol. Symp. 327, 128-149. doi: 10.1002/masy.201350516.

[24] Sondergaard, R., Hosel, M., Angmo, D., Larsen-Olsen, T. T., and Krebs, F. C. (2012). Roll-to-roll fabrication of polymer solar cells. Mater. Today 15, 36-49. doi: 10.1016/S1369-7021 (12) 70019-6

[25] Sun, J. M., Zhu, Y. X., Xu, X. F., Lan, L. F., Zhang, L. J., Cai, P., et al. (2012). High efficiency and high voc inverted polymer solar cells based on a low-lying HOMO polycarbazole donor and a hydrophilic polycarbazole inter layer on ITO cathode. J. Phys. Chem. C 116, 14188-14198. doi: $10.1021 /$ jp3009546.

[26] Deshmukh MK, Deshmukh SS. Modeling of hybrid renewable energy systems. Renewable and Sustainable Energy Reviews 2008; 12: 235-49.
[27] Helal AM, Al-Malek SA, Al-Katheeri ES. Economic feasibility of alternative designs of a PV-RO desalination unit for remote areas in the United Arab Emirates. Desalination 2008; 221: 1-16.

[28] Shaahid SM, Elhadidy MA. Economic analysis of hybrid photovoltaic-diesel-battery power systems for residential loads in hot regions-A step to clean future. Renewable and Sustainable Energy Reviews 2008; 12: 488-503.

[29] Zervas PL, Sarimveis H, Palyvos JA, Markatos NCG. Modelbased optimal control of a hybrid power generation system consisting of photovoltaic arrays and fuel cells. Journal of Power Sources 2008; 181: 327-38.

[30] Katti PK, Khedkar MK. Alternative energy facilities based on site matching and generation unit sizing for remote area power supply. Renewable Energy 2007; 32: 1346-62.

[31] Bitterlin IF. Modelling a reliable wind/PV/storage power system for remote radio base station sites without utility power. Journal of Power Sources 2006; 162: 906-12.

[32] John PB, David GI. A probabilistic method for calculating the usefulness of a store with finite energy capacity for smoothing electricity generation from wind and solar power. Journal of Power Sources 2006; 162: 943-8.

[33] Maclay JD, Brouwer J, Scott Samuelsen G. Dynamic analyses of regenerative fuel cell power for potential use in renewable residential applications. International Journal of Hydrogen Energy 2006; 31: 994-1009.

[34] Nelson DB, Nehrir NH, Wang C. Unit sizing and cost analysis of standalone hybrid wind/PV/fuel cell power generation systems. Renewable Energy 2006; 31: 1641-56.

[35] El-Shatter TF, Eskander MN, El-Hagry MT. Energy flow and management of a hybrid wind/PV/fuel cell generation system. Energy Conversion and Management 2006; 47: 1264-80.

[36] Rajendra Prasad A, Natarajan E. Optimization of integrated photovoltaic-wind power generation systems with battery storage. Energy 2006; 31: 1943-54.

[37] Schmid LA, Hoffmann CAA. Replacing diesel by solar in the Amazon: short-term economic feasibility of PV-diesel hybrid systems. Energy Policy 2004; 32: 881-98.

[38] El-Shatter ThF, Eskandar MN, El-Hagry MT. Hybrid PV/fuel cell system design and simulation. Renewable Energy 2002; 27: 479-85.

[39] Green, M. A. Third generation photovoltaics: Ultra-high conversion efficiency at low cost. Prog. Photovolt. 2001, 9, $123-135$.

[40] M. A. Green, Phys. E, 2002, 14, 65-70.

[41] Conibeer, G. Third-generation photovoltaics. Mater. Today, 2007, 10, 42-50.

[42] Zhao J, Wang A, Green MA, et al. (1998) 19.8\% efficient 'honeycomb' textured multi-crystalline and $24.4 \%$ monocrystalline silicon solar cells. Applied Physics Letters 73: 1991-1993.

[43] Joel Jean, Patrick R. Brown, Robert L. Jaffe, Tonio Buonassisi and Vladimir Bulovic. Pathways for solar photovoltaic. Energy Environ. Sci., 2015, 8, 1200-1219. 
[44] José A. L., Ana M. D., and Rafael P. C. (2019). Materials for Photovoltaic: State of Art and Recent Developments. International Journal of Molecular Science, 20, 976; doi: 10.3390/ijms20040976.

[45] Kirk-Othmer. Silicon. In Kirk-Othmer Encyclopedia of Chemical Technology, 5th ed.; Wiley: Hoboken, NJ, USA, 2007; ISBN 978-0-471-48494-3.

[46] Sampaio, P. G. V.; González, M. O. A. Photovoltaic solar energy: Conceptual framework. Renew. Sustain. Energy Rev. $2017,74,590-601$

[47] Kivambe, M.; Aissa, B.; Tabet, N. Emerging Technologies in Crystal Growth of Photovoltaic Silicon: Progress and Challenges. Energy Procedia 2017, 130, 7-13.

[48] Adamian ZN, Hakhoyan AP, Aroutiounian VM, Barseghian RS, Touryan K. Investigations of solar cells with porous silicon as antireflection layer. Solar Energy Materials \& Solar Cells 2000; 64: 347-51.

[49] Bruton TM. General trends about photovoltaics based on crystalline silicon. Solar Energy Materials \& Solar Cells 2002; 72: $3-10$.

[50] Schlemm H, Mai A, Roth S, Roth D, Baumgartner KM, Mueggeb H. Industrial large scale silicon nitride deposition on photovoltaic cells with linear microwave plasma sources. Surface and Coatings Technology 2003; 174-175: 208-11.

[51] Van der Zwaan B, Rabl A. Prospects for PV: a learning curve analysis. Solar Energy 2003; 74: 19-31.

[52] McCann M, Weber K, Blakers A. Surface passivation by rehydrogenation of silicon-nitride-coated silicon wafers. Progress in Photovoltaics: Research and Applications 2005; 13: $195-200$.

[53] Best Research-Cell Efficiencies (rev. 12-18-2014), National Renewable Energy Laboratory, 2014.

[54] Jayawardena, K. D. G. I.; Rozanski, L. J.; Mills, C. A.; Beliatis, M. J.; Nismy, N. A.; Silva, S. R. P. 'Inorganics-inOrganics': Recent developments and outlook for $4 \mathrm{G}$ polymer solar cells. Nanoscale 2013, 5, 8411-8427.

[55] Chopra, K. L.; Paulson, P. D.; Dutta, V. Thin-film solar cells: An overview. Prog. Photovolt. 2004, 12, 69-92.

[56] Izu, M.; Ovshinsky, S. R.; Deng, X.; Krisko, A.; Ovshinsky, H. C.; Narasimhan, K. L.; Young, R. Continuous roll-to-roll amorphous silicon photovoltaic manufacturing technology. AIP Conf. Proc. 1994, 306, 198-218.

[57] Yang J., Banerjee A., Glatfelter T., Sugiyama S. and Guha S. (1997). Recent progress in amorphous silicon alloy leading to $13 \%$ stable efficiency. Proc. 26th IEEE PVSC, Anaheim, 563-668.

[58] Hishikawa Y., Kinoshita T., Shima M, Tanaka M., Kiyama S., Tsuda S. and Hakano S. (1997). Optical confinement and optical loss in high-efficiency a-Si solar cells. Proc. 26th IEEE PVSC, Anaheim, 615-618.

[59] Handbook of Photovoltaic Science and Engineering, ed. A. Luque and S. Hegedus, 2nd edn, 2011.].

[60] Photovoltaics Report, Fraunhofer ISE, 2014.

[61] D. L. Staebler and C. R. Wronski, Appl. Phys. Lett., 1977, 31, 292-294.
[62] Boutchich M, Alvarez J, Diouf D, et al. (2012) Amorphous silicon diamond based hetero junctions with high rectification ratio. Journal of Non-Crystalline Solids 358: 2110-2113.

[63] Mah O (1998) Fundamentals of photovoltaic materials. National Solar Power Research Institute, Inc. Retrieved from: http://userwww.sfsu.edu/ciotola/solar/pv.pdf

[64] Carlson DE and Wronski CR (1976) Amorphous silicon solar cell. Applied Physics Letters 28: 671-673.

[65] Rech B and Wagner H (1999) Potential of amorphous silicon for solar cells. Applied Physics A Materials Science \& Processing 69: 155-167.

[66] Yang J, Banerjee A, Guha S. Amorphous silicon based photovoltaics-from earth to the "final frontier". Solar Energy Materials \& Solar Cells 2003; 78: 597-612.

[67] Lund CP, Luczak K, Pryor T, Cornish JCL, Jennings PJ, Knipe P, Ahjum F. Field and laboratory studies of the stability of amorphous silicon solar cells and modules. Renewable Energy 2001; 22: 287-94.

[68] Tawada Y, Yamagishi H. Mass-production of large size a-Si modules and future plan. Solar Energy Materials \& Solar Cells 2001; 66: 95-105.

[69] Shirland, F. A, (1996): The history, Design, fabrication and performance of CdS thin film solar cells. A paper presented at the coloque international sur les photopiles en couches minces Marseille, France.

[70] Reynolds, D. C., Leies, G., Antes, L. L. and Marburger, R. E., (1954): Photovoltaic effects in cadmium sulphide, phys. Rev., Volume 96, no. 2, October 15th, 1954, pp 533-534.

[71] Mursheda Hussain, (2004): Vapor $\mathrm{CdCl}_{2}$ processing of $\mathrm{CdTe}$ solar cells. A master's thesis submitted to the department of Electrical engineering, collage of engineering, Florida U. S. A.

[72] Boer KW (2011) Cadmium sulfide enhances solar cell efficiency. Energy Conversion and Management 52: 426-430.

[73] Compaan A. D (2004). The status of and challenges in CdTe thin-film solar-cell technology. MRS Symposium Proceedings 808: 545-555.

[74] Schock HW and Pfisterer F (2011) Thin-film solar cells: past, present and future. Renewable Energy World 4: 75-87.

[75] Razykov TM, Rech B and Tiwari AN (2004) Special issue on thin Film PV. Solar Energy 77: 665-666.

[76] Nowshad A, Takayunki I, Akira Y, et al. (2001) High efficient $1 \mu \mathrm{m}$ thick CdTe solar cells with textured TCOs. Solar Energy Materials and Solar Cells 67: 195-201.

[77] Upadhayaya HM, Razykov TM, Tiwari A, et al. (2007) Photovoltaics fundamentals, technology and application. In: Goswami DY and Kreith F (eds) Handbook of Energy Efficiency and Renewable Energy. New York: CRC Press, pp. 23-1-23-63.

[78] Ferekides C. and Britt J. (1993). Thin film CdS/CdTe solar cell with 15.8\% efficiency. Applied Physics Letter 62: 2851-2852.

[79] Aramoto T, Kumaza S, Higuchi H, et al. (1997) $16.0 \%$ efficient thin-film CdS/CdTe solar cells. Journal of Applied Physics, Part 1: Regular Papers and Short Notes and Review Papers 36: 6304-6305. 
[80] Wu X, Keane JC, DeHart C, et al. (2001) 16.5\% efficient $\mathrm{CdS} / \mathrm{CdTe}$ polycrystalline thin film solar cell. In: Proceedings of the 17th European photovoltaic solar energy conference, Munich, 14-17 October 2001, pp. 995-999.

[81] Goetzberger A, Hebling C, Schock H-W. Photovoltaic materials, history, status and outlook. Materials Science and Engineering: R: Reports 2003; 40: 1-46.

[82] Desai D, Hegedus S, McCandless B, Birkmire R, Dobson K, Ryan D. How CDTE solar cells operate: determining collection using bifacial device character- ization. Photovoltaic energy conversion. In: Proceedings of the conference record of the IEEE fourth world conference; 2006. p. 368-71.

[83] Tang J, Huo Z, Brittman S, Gao H, Yang P. Solution-processed core-shell nanowires for efficient photovoltaic cells. Nature Nanotechnology 2011; 6: 568-72.

[84] Todorov T, Gunawan O, Chey SJ, de Monsabert TG, Prabhakar A, Mitzi DB. Progress towards marketable earthabundant chalcogenide solar cells. Thin Solid Films 2011; 519: 7378-81.

[85] Ferekides CS, Marinskiy D, Viswanathan V, Tetali B, Palekis V, Selvaraj P, Morel DL. High efficiency CSS CdTe solar cells. Thin Solid Films 2000; 361-362: 520-6.

[86] Pfisterer F. The wet-topotaxial process of junction formation and surface treatments of $\mathrm{CuS}-\mathrm{CdS} 2$ thin-film solar cells. Thin Solid Films 2003; 431-432: 470-6.

[87] V. Fthenakis and K. Zweibel, CdTe PV: Real and Perceived EHS Risks, National Center for Photovoltaics Review Meeting, Denver, 2003.

[88] Richards BS, McIntosh KR. Overcoming the poor short wavelength spectral response of $\mathrm{CdS} / \mathrm{CdTe}$ photovoltaic modules via luminescence down-shifting: ray-tracing simulations. Progress in Photovoltaics: Research and Applications 2007; 15: 27-34.

[89] Niki, S.; Contreras, M.; Repins, I.; Powalla, M.; Kushiya, K.; Ishizuka, S.; Matsubara, K. CIGS absorbers and processes. Prog. Photovolt. 2010, 18, 453-466.

[90] Repins I, Conteras M, Egaas B, et al. (2008) 19.9\%-efficient $\mathrm{ZnO} / \mathrm{CdS} / \mathrm{CuInGaSe}{ }_{2}$ solar cell with $81.2 \%$ fill actor. Progress in Photovoltaics: Research and Application 16: 235-239.

[91] Powalla M (2006) The R\&D potential of CIS thin-film solar modules. In: Proceedings of the $21^{\text {st }}$ European photovoltaic solar energy conference, Dresden, September, pp. 1789-1795.

[92] Osborne M (2014) PVTECH. Siva Power claims 18.8\% lab CIGS efficiency. Available at: http://www.pvtech.org/news/siva_power_claims_18.8_lab_cigs_efficiency

[93] M. J. Hetzer, Y. M. Strzhemechny, M. Gao, M. A. Contreras, A. Zunger and L. J. Brillson, Appl. Phys. Lett., 2005, 86, 162105 .

[94] J. Werner, J. Mattheis and U. Rau, Thin Solid Films, 2005, 480-481, 399-409.

[95] S. Nishiwaki, S. Siebentritt, P. Walk and M. Ch. Lux-Steiner, Prog. Photovoltaics, 2003, 11, 243-248.

[96] Otte, K., Makhova, L., Braun, A., and Konovalov, I. 2006. Flexible $\mathrm{Cu}$ (In, Ga) $\mathrm{Se}_{2}$ thin-film solar cells for space application. Thin Solid Films 511-12: 613-22.
[97] Guimard, D., Bodereau, N., Kurdi, J., et al. 2003. Efficient Cu (In, Ga) $\mathrm{Se}_{2}$ based solar cells prepared by electrodeposition. Mater. Res. Soc. Symp. Proc. 763: B6.9.1-6.

[98] Lippold, G., Neumann, H., and Schindler, A. 2001. Ion beam assisted deposition of $\mathrm{Cu}$ (In, Ga) $\mathrm{Se}_{2}$ films for thin film solar cells. Mater. Res. Soc. Symp. Proc. 668: H3.9.1-6.

[99] Mitzi, D. B., Yuan, M., Liu, W., et al. 2009. Hydrazine-based deposition route for device quality CIGS films. Thin Solid Films 517: 2158-62.

[100] Li, X. C., Soltesz, I., Wu, M., Ziobro, F., Amidon, R., and Kiss, Z. 2008. A nanoparticle ink printing process for all printed thin film copper-indium-selenide (CIS) solar cells. In Proceedings of the SPIE: Nanoscale Photonic and Cell Technologies for Photovoltaics, San Diego, CA, August, 7047: 70470E-70470E-9.

[101] Matsunaga, K., Komaru, T., Nakayama, Y., Kume, T., and Suzuki, Y. 2009. Mass-production technology for CIGS modules. Solar Energy Mater. Solar Cells, 93: 1134-8.

[102] Green, M. A. 2003. Third generation photovoltaics: Advanced solar energy conversion. Berlin: Springer-Verlag.

[103] Martí, A.; Luque, A. Next Generation Photovoltaics: High Efficiency through Full Spectrum Utilization; CRC Press: Boca Raton, FL, USA, 2003; p. 136, ISBN 9780750309059.

[104] Tandem Solar Cells. Available online: http://plasticphotovoltaics.org/lc/lc-polymersolarcells/lctandem.html

[105] Loucas T. (2010). Nanotechnology for Photovoltaics. Taylor and Francis Group LLC, Boca Raton.

[106] Marti, A., and Araujo, G. L. 1996. Limiting efficiencies for photovoltaic energy conversion in multigap systems. Solar Energy Mater. Solar Cells 43: 203.

[107] Goetzberger A and Hoffmann VU (2005) Photovoltaic solar energy generation. Springer Series in Optical Sciences, p.112.

[108] Yamaguchi M, Nishimura K, Sasaki T, et al. (2008) Novel materials for high-efficiency III-V multijunction solar cells. Solar Energy 82: 173-180.

[109] Shockley W and Queisser HJ (1961) Detailed balance limit of efficiency of $\mathrm{p}-\mathrm{n}$ junction solar cells. Journal of Applied Physics 32 (3): 510-519.

[110] Guha S (2004) Thin film silicon solar cells grown near the edge of amorphous to microcrystalline transition. Solar Energy 77: 887-892.

[111] Diefenbach KH (2005) Wiped away. Photon International, February: pp. 48-67.

[112] Yamamoto K, Nakajima A, Yoshimi M, et al. (2004) A high efficiency thin film silicon solar cell and module. Solar Energy 77: 939-949.

[113] Wesoff E (2013) GreentechSolar. Sharp hits record 44.4\% efficiency for triple-junction solar cell. Available at: http://www.greentechmedia.com/articles/read/Sharp-HitsRecord-44.4-Efficiency-For-Triple-Junction-Solar-Cell

[114] Hoppe, H. and Sariciftci, N. S. (2008) Polymer Solar Cells. Advances in Polymer Science, 214, 1. 
[115] Almosni, S.; Delamarre, A.; Jehl, Z.; Suchet, D.; Cojocaru, L.; Giteau, M.; Behaghel, B.; Julian, A.; Ibrahim, C.; Tatry, L.; et al. Material challenges for solar cells in the twenty-first century: Directions in emerging technologies. Sci. Technol. Adv. Mater. 2018, 19, 336-369.

[116] Tian, J.; Cao, G. Semiconductor quantum dot-sensitized solar cells. Nano Rev. 2013, 4, 22578.

[117] Yoshitaka O.; Jiko Soshiki ka Ryoshi Dotto Cho Koshi to Kokuritsu Taiyo Denchiheno Oyo; (2006). Application to selfassembler quantum dot super-grid and highly effective solar battery. The Japanese Association for Crystal Growth Cooperation (JACG) Magazine. Volume 33, Number 2.

[118] Yoshitaka O.; Ryuji O.; Ryoshi; Nano Kozo wo Donyu Shita Jisedai Taiyo Denchi; (2007). The next generation solar battery that introduces quantum nano-structure. Applied physics. Volume76, Number 1.

[119] Zin, N. S.; McIntosh, K.; Fong, K.; Blakers, A. High Efficiency Silicon Solar Cells. Energy Procedia 2013, 33, 1-10.

[120] Luther, J. M.; Gao, J.; Lloyd, M. T.; Semonin, O. E.; Beard, M. C.; Nozik, A. J. Stability assessment on a $3 \%$ bilayer $\mathrm{PbS} / \mathrm{ZnO}$ quantum dot heterojunction solar cell. Adv. Mater. 2010, 22, 3704-3707.

[121] Mora-Seró, I.; Bisquert, J. Breakthroughs in the Development of Semiconductor-Sensitized Solar Cells. J. Phys. Chem. Lett. 2010, 1, 3046-3052.

[122] Du, J.; Du, Z.; Hu, J.-S.; Pan, Z.; Shen, Q.; Sun, J.; Long, D.; Dong, H.; Sun, L.; Zhong, X.; et al. Zn-Cu-In-Se Quantum Dot Solar Cells with a Certified Power Conversion Efficiency of 11.6. J. Am. Chem. Soc. 2016, 138, 4201-4209.

[123] Sogabe, T.; Shen, Q.; Yamaguchi, K. Recent progress on quantum dot solar cells: A review. J. Photonics Energy 2016, 6, 040901 .

[124] Luque, A.; Martí, A. Increasing the efficiency of ideal solar cells by photon induced transitions at intermediate levels. Phys Rev Lett. 1997, 78, 5014-5017.

[125] Antolin E., Marti A., Stanley C. R., Farmer C. D., Canovas E., Lopez N., Linares P. G., Luque A. (2008). Low temperature characterization of the photocurrent produced by two-photon transitions in a quantum dot intermediate band solar cell. Thin Solid Films; 516: 6716-22.

[126] Hagfeldt A., Boschloo G., Sun L., Kloo L. and Pettersson H., (2010). Chemical Review, 110, 6595-6663.

[127] Gratzel M. (2005). Inorganic Chemistry, 44, 6841-6851.

[128] Gratzel M. (2003). Journal of Photochemistry and Photobioliogy, C, 4, 145-153.

[129] Srinivas, B., Balaji, S., Nagendra Babu, M. and Reddy, Y. S. (2015). Review on Present and Advance Materials for Solar Cells. International Journal of Engineering Research-Online, $3,178-182$.

[130] Han, L., Fukui, A., Fuke, N., Koide, N., and Yamanaka, R. (2006). High efficiency of dye-sensitized solar cell and module. In Proceedings of the IEEE 4th World Conference on Photovoltaic Energy Conversion, Vol. 1, Waikoloa, HI, May 7-12, p. 179.

[131] Li, B., Wang, L., Kang, B., Wang, P. and Qiu, Y. (2006). Review of Recent Progress in Solid-State Dye-Sensitized Solar Cells. Solar Energy Materials and Solar Cells, 90, 549-573.
[132] Graetzel, M., Janssen, R. A. J., Mitzi, D. B. and Sargent, E. H. (2012). Materials Interface Engineering for SolutionProcessed Photovoltaics. Nature, 488, 304-312.

[133] Suhaimi, S., Shahimin, M. M., Alahmed, Z. A., Chyský, J. and Reshak, A. H. (2015). Materials for Enhanced DyeSensitized Solar Cell Performance: Electrochemical Application. International Journal of Electrochemical Science, 10, 28-59.

[134] Liang, M., Xu, W., Cai, F. S., Chen, P. Q., Peng, B., Chen, J. and Li, Z. M. (2007). New Triphenylamine-Based Organic Dyes for Efficient Dye-Sensitized Solar Cells. The Journal of Physical Chemistry C, 111, 4465-4472.

[135] Millington, K. R.; Fincher, K. W.; King, A. L. (2007). Mordant dyes as sensitisers in dye-sensitised solar cells. Solar Energy Material Solar Cells, 91, 1618-1630.

[136] Kim M-J, Yu Y-J, Kim J-H, Jung Y-S, Kay K-Y, Ko S-B, et al. (2012). Tuning of spacer groups in organic dyes for efficient inhibition of charge recombination in dye-sensitized solar cells. Dyes and Pigments; 95: 134-41.

[137] Hara M. K. and Arakawa H. (2003). Dye-sensitized solar cells, Handbook of Photovoltaic Science and Engineering, ed A Luque and S Hegedus, J Wiley (New York), 663-700.

[138] Li V., Zhu R. and Yang Y., (2012). Nature Photonics, 6, 153161.

[139] Kippelen B. and Bredas J. L., (2009). Energy and Environmental Science, 2, 251-261.

[140] Riede V, Mueller T., Tress W., Schueppel R. and Leo K., (2008). Nanotechnology, 19, 424001.

[141] Gunes S., Neugebauer H. and Sariciftci N. S., (2007). Chemical Review, 107, 1324-1338.

[142] Shaheen S. E., Ginley D. S. and Jabbour G. E., (2005). MRS Bulletin, 30, 10-19.

[143] Coakley K. M. and McGehee M. D., (2004). Chemical Materials, 16, 4533-4542.

[144] Hoppe H. and Sariciftci N. S. (2004). Journal of Material Research, 19, 1924-1945.

[145] Peumans P., Yakimov A. and Forrest S. R. (2003). Journal of Applied Physics, 93, 3693.

[146] Wohrle D. and Meissner D., (1991). Advanced Materials, 3, 129-138.

[147] Forrest, S. D. (2005). The limits to organic photovoltaic cell efficiency. MRS Bulletin 30: 28-21.

[148] Dou L. T., You J. B., Yang J., Chen C. C., He Y. J., Murase S., Moriarty T., Emery K., Li G., Yang Y. (2012). Tandem polymer solar cells featuring a spectrally-matched low bandgap polymer. Nature Photonics; $6: 180-5$.

[149] Jorgensen M, Norrman K, Krebs F. C. (2008). Stability/degradation of polymer solar cells. Solar Energy Materials \& Solar Cells; 92: 686-714.

[150] Dennler G, Scharber M. C, Ameri T, Denk P, Forberich K, Waldauf C, Brabec C. J. (2008). Design rules for donors in bulk-heterojunction tandem solar cells-towards $15 \%$ energy conversion efficiency. Advanced Materials; 20: 579-83. 
[151] Yue S., Bin L., Di F., Ziruo H., Wenlian L. (2007). Rhenium (I) complex as an electron acceptor in a photovoltaic device. Journal of Alloys and Compounds; 432: L15-7.

[152] Mozer A. J, Sariciftci N. S. (2006). Conjugated polymer photovoltaic devices and materials. C R Chimie; 9: 568-77.

[153] Shrotriya V, Wu E. H. E, Li G, Yao Y, Yang Y. (2006). Efficient light harvestingin multiple-device stacked structure for polymer solar cells. Applied Physics Letter; 88, 064104/13.

[154] Wei H, Li W, Li M, Su W, Xin Q, Niu J, Zhang Z, Hu Z. (2006). White organic electroluminescent device with photovoltaic performances. Applied Surface Science; 252: 2204-8.

[155] Bernede J. C, Derouiche H, Djara V. (2005). Organic photovoltaic devices: influence of the cell configuration on its performances. Solar Energy Materials and Solar Cells; 87: 261-70.

[156] Yakimov A, Forrest S. R. (2002). High photovoltage multipleheterojunctionorganic solar cells incorporating interfacial metallic nanoclusters. Applied Physics Letter; 80: 1667-9.

[157] Eperon, G. E.; Stranks, S. D.; Menelaou, C.; Johnston, M. B.; Herz, L. M.; Snaith, H. J. (2014). "Formamidinium lead trihalide: a broadly tunable perovskite for efficient planar heterojunction solar cells". Energy \& Environmental Science 7 (3): 982

[158] Noel, N. K.; Stranks, S. D.; Abate, A.; Wehrenfennig, C.; Guarnera, S.; Haghighirad, A.; Sadhanala, A.; Eperon, G. E.; Pathak, S. K.; Johnston, M. B.; Petrozza, A.; Herz, L. M.; Snaith, H. J. (2014). "Lead-free organic-inorganic tin halide perovskites for photovoltaic applications". Energy \& Environmental Science 7 (9): 3061

[159] Kojima, A.; Teshima, K.; Shirai, Y.; Miyasaka, T. (2009). Organometal halide perovskites as visible-light sensitizersvfor photovoltaic cells. Journal American Chemical Society, 131, 6050-6051.

[160] Djurisic, A. B.; Liu, F. Z.; Tam, H. W.; Wong, M. K.; Ng, A.; Surya, C.; Chen, W.; He, Z. B. (2017). Perovskite solar cellsAn overview of critical issues. Progress on Quantum Electron. $53,1-37$.

[161] Salhi, B.; Wudil, Y. S.; Hossain, M. K.; Al-Ahmed, A.; AlSulaiman, F. A. (2018). Review of recent developments and persistent challenges in stability of perovskite solar cells. Renewable Sustainable Energy Review, 90, 210-222.
[162] Nam-Gyu P. (2013). Organometal Perovskite Light Absorbers toward a 20\% Efficiency Low-Cost Solid-State Mesoscopic Solar Cell. Journal of Physical chemistry letters, 4, 24232429.

[163] PV Education. Retrieved from: http://www.pveducation.org

[164] Kim, H.-S. et al. (2012). Sci. Rep. 2, 591.

[165] Im, J.-H. et al. (2011). Nanoscale, 3, 4088-4093.

[166] Research Cell Efficiency Records, NREL. Available at: http://www.nrel.gov/ncpv/

[167] P. R. Brown, D. Kim, R. R. Lunt, N. Zhao, M. G. Bawendi, J. C. Grossman and V. Bulovi'c, ACS Nano, 2014, 8, 58635872 .

[168] A. H. Ip, S. M. Thon, S. Hoogland, O. Voznyy, D. Zhitomirsky, R. Debnath, L. Levina, L. R. Rollny, G. H. Carey, A. Fischer, K. W. Kemp, I. J. Kramer, Z. Ning, A. J. Labelle, K. W. Chou, A. Amassian and E. H. Sargent, Nat. Nanotechnol., 2012, 7, 577-582.

[169] J. Jasieniak, M. Califano and S. E. Watkins, ACS Nano, 2011, $5,5888-5902$.

[170] J. Tang, K. W. Kemp, S. Hoogland, K. S. Jeong, H. Liu, L. Levina, M. Furukawa, X. Wang, R. Debnath, D. Cha, K. W. Chou, A. Fischer, A. Amassian, J. B. Asbury and E. H. Sargent, Nat. Mater., 2011, 10, 765-771.

[171] D. D. Wanger, R. E. Correa, E. A. Dauler and M. G. Bawendi, Nano Lett., 2013, 13, 5907-5912.

[172] D. Zhitomirsky, O. Voznyy, L. Levina, S. Hoogland, K. W. Kemp, A. H. Ip, S. M. Thon and E. H. Sargent, Nat. Commun., 2014, 5, 3803.

[173] M. A. Green, A. Ho-Baillie and H. J. Snaith, Nat. Photonics, 2014, 8, 506-514.

[174] K. Kawano, R. Pacios, D. Poplavskyy, J. Nelson, D. D. C. Bradley and J. R. Durrant, Sol. Energy Mater. Sol. Cells, 2006, 90, 3520-3530.

[175] G. Li, R. Zhu and Y. Yang, Nat. Photonics, 2012, 6, 153-161.

[176] R. R. Lunt, T. P. Osedach, P. R. Brown, J. A. Rowehl and V. Bulovi'c, Adv. Mater., 2011, 23, 5712-5727. 